\title{
THERMAL MODIFICATION OF EUCALYPTUS WOOD AND USE FOR FLOORS OF LOW TRAFFIC ENVIRONMENTS
}

\author{
Claudio Gumane Francisco Juizo ${ }^{1 *}$, Marcio Pereira da Rocha ${ }^{2}$, Carolina Nogueira Xavier ${ }^{3}$, Ana Clara Moreira
} Moraes $^{3}$, Mônica Bezerra de Oliveira ${ }^{3}$, José Reinaldo Moreira da Silva ${ }^{3}$

\author{
1*Instituto Superior Politécnico de Manica, Divisão de Agricultura, Engenharia Florestal, Vanduzi, Manica-Moçambique -e.mail: \\ c.gumane@gmail.com \\ ${ }^{2}$ Universidade Federal do Paraná, Departamento de Engenharia e Tecnologia Florestal, Engenharia Florestal, Curitiba, Paraná-Brasil- e.mail: \\ mprocha01@gmail.com \\ ${ }^{3}$ Universidade Federal de Lavras, Departamento de Ciências Florestais, Ciências Florestais, Lavras, Minas Gerais-Brasil, e.mail: \\ ncarolx@gmail.com; anclaramm@hotmail.com; m.bezerradeoliveira@gmail.com; jreinaldoms@gmail.com
}

Received for publication: 24/10/2019 - Accepted for publication: 15/04/2020

\begin{abstract}
Resumo
Modificação térmica da madeira de Eucalyptus e uso para pisos de ambientes de baixo trafego. O objetivo deste trabalho foi avaliar o efeito da modificação térmica na dureza superficial e depressões por aplicação de cargas na obtenção de pisos para ambientes de baixo tráfego. Foram utilizados quatro clones dos quais foram obtidos toras e desdobradas em tábuas secas ao tempo, em seguida agrupadas para testes na condição natural (NT) e amostras modificadas termicamente a 200 graus Celsius por quatro horas (T), utilizando um programa com aquecimento de 1 grau por minuto, num forno elétrico. Em seguida nas amostras de cada clone foram avaliadas a perda de massa, massa especifica aparente, teor de lignina e de holoceluloses, dureza Janka, depressões por impacto por queda de esfera, depressões por carga distribuída e depressões por carga concentrada utilizando um equipamento sobre trilhos transferindo carga de $890 \mathrm{~N}$ para as madeiras a de 0,06 $\mathrm{m} . \mathrm{s}^{-1}$. Nos resultados verificou-se maior perda de massa no clone E. grandis x E. urophylla de polinização controlada. Os teores de lignina apresentaram aumentos, e os teores de holoceluloses apresentaram decréscimos significativos após modificação térmica. Houve redução da dureza Janka nas madeiras com exceção do clone E. urophylla que apresentou menores depressões no teste de queda de esfera após a modificação térmica. Verificou-se aumentos de depressões em ensaios de carga concentrada e distribuída, após a modificação térmica. E o clone E. urophylla de seleção massal apresentou menores depressões após 25 e 50 passadas respectivamente, sendo o mais recomendado para obtenção de pisos para saunas, decks de jardins, piscinas, por não necessitar de maiores exigências de carga.

Palavras-chave: Massa especifica aparente, dureza Janka, endentação, carga concentrada, carga distribuída.
\end{abstract}

\begin{abstract}
The aim of this work was to evaluate the effect of thermal modification on surface hardness and depressions by applying loads to obtain floors for low traffic environments. Four clones were used from which logs were obtained and split into boards dried in time, and grouped for testing in their natural condition (NT) and thermally modified at 200 degrees Celsius for four hours (T) in a schedule with a heating of 1 degree per minute, on electric oven. Then in the samples from each clone were evaluated the mass loss, specific gravity, lignin and holocelluloses content, Janka hardness, fall ball impact depressions, distributed load depressions, and concentrated load depressions using track equipment which transfer a load of $890 \mathrm{~N}$ to the woods at a speed of $0.06 \mathrm{~ms}^{-1}$. In the results verified high mass loss in the E. grandis $\mathrm{x}$ E. urophylla clone from controlled polination. The lignin contents showed increases and holocelluloses contents showed significant decreases after thermal modification. There was a reduction in Janka hardness in the woods with the exception of E. urophylla clone which presented lower depressions in the fall ball test after thermal modification. Verified increasing in depressions in the concentrated and distributed load tests, after thermal modification. And the E. urophylla clone presented lower depressions after 25 and 50 passes respectively, being the most recommended for obtaining floors for saunas, garden decks, swimming pools as it does not require high loading requirements. Keywords: Apparent specific gravity, Janka Hardness, Indentation, Concentrated Load, distributed.
\end{abstract}

\section{INTRODUCTION}

In recent years there has been an increasing use of eucalyptus wood for pulping, furniture and civil construction, mainly in the South and Southeast regions of Brazil. Padilha et al. (2006) claim this situation to the best known comparative and competitive advantages of these species, but also to the growing demand for alternatives in view of the restrictions imposed on the use of wood from native forests, associated with the growing need for product diversification in industrialization.

For Ibá (2017), a considerable part of this eucalyptus wood is exported, an activity that has been growing in recent years due to the increase in the production of Products with Higher Added Value (PHAV), bringing considerable contributions to the trade balance, through the generation of jobs. Despite the slowdown in civil 
construction in the beginning and mid of the present decade, there has been an increase in the consumption of eucalyptus wood, in obtaining laminates, floors, floors and decks. However, this consumption is still limited, due to the restrictions imposed by the characteristics of the eucalyptus species in the most diversified uses.

In the specific case of the flooring industry, the use of wood from these species remains limited, as a result of the variation in color, dimensional instability and limitations in relation to the environments of use in service, which makes them more suitable for internal uses and with little variation in light and humidity, as a way to reduce the marked anisotropic effect that is characteristic of these species. Thus, the chemical modifications that occur after the thermal modification reduce the possibilities of delamination and attack by xylophagous organisms, without compromising the aesthetics of the place and causing economic damage, due to the need to replace parts after installation.

Allied to this, Padilha et al. (2006) reported good characteristics of coloring, design, hardness, abrasion, resistance to humidity, natural durability and heat transfer, indicating as being essential for the production of floors. For this, Modes et al. (2017) stated the need to perform thermal modification to improve the surface hardness and reduce the flexibility of the wood; aspects that, for Hardwood Review (2009), are important and justify the suitability for using wood in these applications, as they are cozy and appreciated for installation in residential and commercial environments.

Nevertheless, the Hardwood Review (2009) reported the use of eucalyptus and cedar wood floors submitted to thermal modification, in seaside environments, saunas, garden decks and children's playgrounds with success, replacing nobler and more expensive woods such as Teak and Ipê.

This indicates the possibility of using these woods for similar uses in Brazil. However, they need evaluations through simulation of use in service, it was in this sense that this research was developed to evaluate the effect of thermal modification on surface hardness and depressions by applying loads in obtaining floors for light traffic environments.

\section{MATERIALS AND METHODS}

\section{Sampling}

Four eucalyptus clones from a 10-year-old experimental plantation located on the Santa Terezinha farm of the International Paper company in Mogi Guaçu-São Paulo were used. From each clone five trees were selected and felled from where logs from each tree were obtained, which were unfolded in a double circular saw, to obtain the semi-block that was resurfaced in a multiple circular saw with two axes, obtaining boards with nominal dimensions of $120 \mathrm{~mm}$ x $28 \mathrm{~mm}$ x $2000 \mathrm{~mm}$ for Length $\mathrm{x}$ Width $\mathrm{x}$ Thickness (LxWxT). Table 1 shows the description and combination of matrices used to obtain the said clones.

Table 1. Indication of eucalyptus clones and their species used in the experiment.

Tabela 1. Indicação dos clones de eucalipto e as respectivas espécies utilizadas no experimento.

\begin{tabular}{ll}
\hline \multicolumn{1}{c}{ Clones } & \multicolumn{1}{c}{ Origin } \\
\hline E. grandis $\mathrm{x}$ E. urophylla & Masal selection \\
E. grandis & Masal selection \\
E. grandis $\mathrm{x}$ E. urophylla & Controlled pollination \\
E. urophylla & Masal selection \\
\hline
\end{tabular}

The obtained boards were dried over time to $20 \%$ humidity and subsequently separated into two groups of 40 pieces per clone; the first group for wood in the natural condition (In natura) - (NT) and the second group for thermally modified wood (T) when using an electric oven from Linn Elektro Therm, model $k k 260$ available in the Chemical Engineering laboratory with a combination of 200 degrees of exposure for four hours as seen in the program shown in Figure 1.

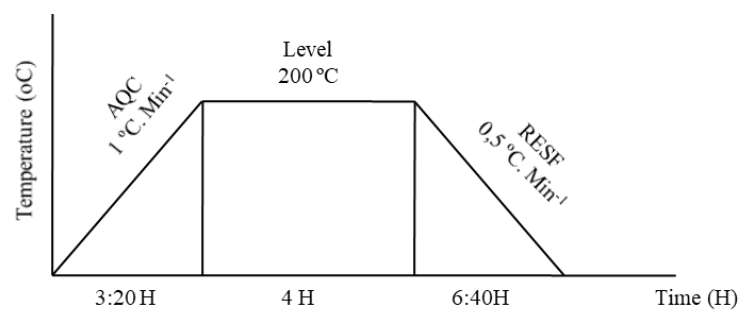

Figure 1. Thermal modification program used in the experiment.

FLORESTA, Curitiba, PR, v. 51, n. 2, p. 457-465, abril/jun 2021.

Juizo, C. G. F. et.al.

ISSN eletrônico 1982-4688 
Figura 1. Programa de modificação térmica utilizado no experimento.

AQC- Heating; Level- Thermal modification itself; RESF-Cooling.

Source: Author (2019)

A heating range of one degree per minute and 0.5 degrees of cooling was used to control defects and stresses that may occur during the process.

\section{Physical properties}

For the physical properties of the wood, loss of mass due to thermal modification and apparent specific mass were considered. Mass loss was assessed using sample weight values before and after thermal modification, according to the methodology used by Cademartori et al. (2015). The apparent specific mass of the wood of the 4 clones was determined in samples previously conditioned in a climatic chamber reaching $12 \pm 2 \%$ and $8 \pm 2 \%$ of equilibrium humidity in natura and thermally modified conditions respectively.

\section{Chemical properties}

The content of lignin and holocelluloses in crushed wood was determined and classified in a sieve with three meshes, using material retained in the 60 mesh mesh to promote greater contact of the wood with the chemical solvents, according to the determination of TAPPI 204 (1997) and TAPPI 222 (1998).

\section{Surface hardness}

Then, Janka hardness tests were carried out according to the recommendations of the ASTM D 143-14 (2014) standard, with the aid of the EMIC universal testing machine with a capacity of 10T, equipped with a $500 \mathrm{kgf}$ load cell. For this purpose, 12 specimens were used, which were placed in a climatic chamber to stabilize humidity in $12 \pm 2$ and $8 \pm 2$ for fresh and thermally modified wood, respectively.

\section{Falling ball}

The impact test for ball falls was carried out in a $180 \mathrm{~cm}$ high metal tower, in which 12 specimens of each condition of the wood were accommodated, with dimensions of $240 \mathrm{~mm}$ x $100 \mathrm{~mm}$ x $20 \mathrm{~mm}$. These were covered with a sheet of carbon paper on the surface to enhance the impact area and the spherical cap of the $51 \mathrm{~mm}$ diameter and $535 \mathrm{~g}$ mass. Four heights of falling of ball were considered $(30 \mathrm{~cm}, 60 \mathrm{~cm}, 150 \mathrm{~cm}$ and $180 \mathrm{~cm})$, which were measured the respective depressions according to the methodology proposed by ASTM D2394-83 (2011).

\section{Concentrated load}

Concentrated load tests were carried out to measure the damage in the form of depressions in the specimens with dimensions of $240 \mathrm{~mm}$ x $100 \mathrm{~mm}$ x $20 \mathrm{~mm}$ (LxWxT), for both wood conditions. The samples were positioned at an angle of $45^{\circ}$ between the axial axis of the wood and the direction of displacement of the load applied by equipment on rails with a wheel in the center at a speed of $0.06 \mathrm{~m} \cdot \mathrm{s}^{-1}$ for 25 and 50 passes, in back and forth movements, simulating the scraping of objects on the same point on the surface of the floors, as is the case with scraping of furniture, appliances and musical instruments, according to the recommendation of the ASTM D2394-83 (2011) standard.

\section{Distributed load test}

In the simulation of distributed load carried out on specimens with dimensions of $240 \mathrm{~mm} \times 100 \mathrm{~mm} \times$ $20 \mathrm{~mm}$ (LxWxT), a cylindrical roller of $890 \mathrm{~N}$ with 225 teeth of $5 \mathrm{~mm}$ in diameter was used; transferring the load in a distributed way to the wood at a speed of $0.06 \mathrm{~m} . \mathrm{s}^{-1}$ during 50 round trips, simulating damage caused in small areas by the movement of sharp objects or walking with the tip of heels over the floors as proposed by ASTM D2394-83 (2011) methodology.

\section{Statistical analysis}

The Janka hardness data, depressions under rolling load and depressions under distributed load were analyzed in Statgraphics centurion XV, in which the homogeneity test was performed, followed by analysis of variance in a factorial experiment considering two factors (condition of the wood at two levels and eucalyptus clones at four levels).

When a significant difference was detected between treatments, the Tukey test at $5 \%$ significance was used to select the resistance limit of each clone according to the condition of the wood.

For the depressions caused by impact on the steel ball, regression analysis was performed using the pairs of indentation values caused and the respective drop height of the ball, to obtain the indentation index and maximum depression limit supported in natura and thermally modified wood.

\section{RESULTS}


It can be seen in Table 2 that in natura and thermally modified woods of the 4 clones, the apparent specific mass was statistically equal. And the thermal modification of E. grandis x E. urophylla of masal selection and $E$. grandis caused a non-significant reduction in apparent specific mass; while in E. grandis $\mathrm{x}$ E. urophylla with controlled pollination and E. urophylla the temperature and time of exposure resulted in a non-significant increase in this property. However, in the chemical analyzes of the four clones, significant increases in lignin levels and significant decreases in holecellulose levels were observed after the thermal modification.

Table 2. Physical and chemical properties of natural and thermally modified wood in the four eucalyptus clones.

Tabela 2. Propriedades físicas e químicas da madeira in natura e modificada termicamente nos quatro clones de eucalipto.

\begin{tabular}{|c|c|c|c|c|c|c|}
\hline \multirow[b]{2}{*}{ Property } & \multirow[b]{2}{*}{$\mathrm{T}$. } & \multicolumn{4}{|c|}{ Clones } & \multirow[b]{2}{*}{$\mathrm{F}$} \\
\hline & & $\begin{array}{l}\text { E.grandis } \\
\mathrm{x} \text { E.urophylla } \\
\text { Masal selection }\end{array}$ & $\begin{array}{l}\text { E.grandis } \\
\text { Masal selection }\end{array}$ & $\begin{array}{l}\text { E.grandis } \\
\mathrm{x} \text { E.urophylla } \\
\text { Controlled } \\
\text { pollination }\end{array}$ & $\begin{array}{l}\text { E.urophylla } \\
\text { Masal selection }\end{array}$ & \\
\hline \multirow{2}{*}{$\operatorname{MEA}\left(\mathrm{g} \cdot \mathrm{cm}^{-3}\right)$} & NT & $\begin{array}{l}0.49 \\
*(1.81)\end{array}$ & $\begin{array}{l}0.59 \\
*(3.36)\end{array}$ & $\begin{array}{l}0.50 \\
*(4)\end{array}$ & $\begin{array}{l}0.59 \\
*(2.27)\end{array}$ & \multirow[b]{2}{*}{$4.9 \mathrm{~ns}$} \\
\hline & $\mathrm{T}$ & $\begin{array}{l}0.46 \\
*(4.95)\end{array}$ & $\begin{array}{l}0.52 \\
*(4.37)\end{array}$ & $\begin{array}{l}0.61 \\
*(5.72)\end{array}$ & $\begin{array}{l}0.65 \\
*(2.0)\end{array}$ & \\
\hline \multirow[b]{2}{*}{ PM (\%) } & NT & - & - & - & - & \multirow[b]{2}{*}{$4.7^{*}$} \\
\hline & $\mathrm{T}$ & $\begin{array}{l}18.66 \mathrm{~B} \\
*(5.19)\end{array}$ & $\begin{array}{l}18.72 \mathrm{~B} \\
*(7.06)\end{array}$ & $\begin{array}{l}22.72 \mathrm{~A} \\
*(6.55)\end{array}$ & $\begin{array}{l}17.07 \mathrm{~B} \\
*(8.04)\end{array}$ & \\
\hline \multirow{2}{*}{$\mathrm{L}(\%)$} & NT & $\begin{array}{l}26.98 \mathrm{aA} \\
*(6.73)\end{array}$ & $\begin{array}{l}27.16 \mathrm{bA} \\
*(1.33)\end{array}$ & $\begin{array}{l}25.56 \mathrm{bA} \\
*(1.43)\end{array}$ & $\begin{array}{l}26.10 \mathrm{bA} \\
*(1.13)\end{array}$ & \multirow{2}{*}{$6.7^{*}$} \\
\hline & $\mathrm{T}$ & $\begin{array}{l}27.18 \mathrm{aB} \\
*(3.94)\end{array}$ & $\begin{array}{l}29.76 \mathrm{aA} \\
*(0.65)\end{array}$ & $\begin{array}{l}28.92 \mathrm{aAB} \\
*(1.31)\end{array}$ & $\begin{array}{l}30.18 \mathrm{aA} \\
*(1.24)\end{array}$ & \\
\hline \multirow{2}{*}{$\mathrm{H}(\%)$} & NT & $\begin{array}{l}67.49 \mathrm{aB} \\
*(2.56)\end{array}$ & $\begin{array}{l}68.52 \mathrm{aAB} \\
*(0.72)\end{array}$ & $\begin{array}{l}70.09 \mathrm{aA} \\
*(0.92)\end{array}$ & $\begin{array}{l}69.16 \mathrm{aAB} \\
*(0.51)\end{array}$ & \multirow{2}{*}{$17.8^{*}$} \\
\hline & $\mathrm{T}$ & $\begin{array}{l}65.28 \mathrm{bA} \\
*(1.49)\end{array}$ & $\begin{array}{l}60.94 \mathrm{bB} \\
*(0.45)\end{array}$ & $\begin{array}{l}62.69 \mathrm{bB} \\
*(0.26)\end{array}$ & $\begin{array}{l}61.41 \mathrm{bB} \\
*(0.39)\end{array}$ & \\
\hline
\end{tabular}

Averages followed by the same capital letter on the line, do not differ by Tukey's test $*$ Significant at $95 \%$ probability $(0.01=<\mathrm{p}<0.05)$. ns: Not significant $(\mathrm{p}>=0.05) ;{ }^{*}$ Value in parentheses is coefficient of variation of the samples.

Where: T - Treatment; NT - Wood in natura; T - Thermally modified wood; MEA - apparent specific mass; PM - Weight loss; L - Lignin; H - Holocelluloses.

\section{Janka hardness and steel ball impact}

In Table 3, for the qualification of the surface and environments of use in natura and thermally modified wood floors of the four eucalyptus clones, it can be observed that the Janka hardness and depressions in falling steel ball, showed significant differences between the four clones.

Table 3. Janka hadness and steel ball impact depressions in the wood surface of four Eucalyptus clones.

Tabela 3. Dureza Janka e depressões por impacto de esfera de aço na superfície da madeira de quatro clones de eucalipto.

\begin{tabular}{|c|c|c|c|c|c|c|}
\hline \multirow[t]{2}{*}{ Variable } & \multirow[t]{2}{*}{$\mathrm{T}$. } & \multicolumn{2}{|l|}{ Clones } & \multirow[b]{2}{*}{$\begin{array}{l}\text { E.grandis } \\
\mathrm{x} \text { E.urophylla } \\
\text { Controlled } \\
\text { pollination }\end{array}$} & \multirow[b]{2}{*}{$\begin{array}{l}\text { E.urophylla } \\
\text { Masal } \\
\text { selection }\end{array}$} & \multirow[b]{2}{*}{$\mathrm{F}$} \\
\hline & & $\begin{array}{l}\text { E.grandis } \\
\mathrm{x} \text { E.urophylla } \\
\text { Masal selection }\end{array}$ & $\begin{array}{l}\text { E.grandis } \\
\text { Masal } \\
\text { selection }\end{array}$ & & & \\
\hline \multirow{4}{*}{$\begin{array}{l}\text { JH } \\
\text { (Mpa) }\end{array}$} & NT & $25.76 \mathrm{Cb}$ & $30.96 \mathrm{Ba}$ & $25.96 \mathrm{Ca}$ & $37.73 \mathrm{Aa}$ & \multirow[t]{4}{*}{$4.23 *$} \\
\hline & & $*(33.14)$ & $*(18.84)$ & $*(28.90)$ & $*(18.07)$ & \\
\hline & $\mathrm{T}$ & $23.03 \mathrm{Bb}$ & $24.82 \mathrm{Bb}$ & $22.96 \mathrm{Ba}$ & $45.02 \mathrm{Ab}$ & \\
\hline & & $*(24.4)$ & $*(14.43)$ & $*(16.64)$ & $*(24.10)$ & \\
\hline \multirow{4}{*}{$\begin{array}{l}\text { SID } \\
(\mathrm{mm})\end{array}$} & NT & $0.63 \mathrm{Aa}$ & $0.67 \mathrm{Aa}$ & $0.85 \mathrm{Aa}$ & $0.65 \mathrm{Aa}$ & \multirow[t]{4}{*}{$3.02 *$} \\
\hline & & $*(26.14)$ & $*(18.18)$ & $*(10.50)$ & $*(12.30)$ & \\
\hline & $\mathrm{T}$ & $1.10 \mathrm{Ab}$ & $1.04 \mathrm{Ab}$ & $1.13 \mathrm{Ab}$ & $0.65 \mathrm{Bb}$ & \\
\hline & & $*(27.09)$ & $*(14.61)$ & $*(26.75)$ & $*(19.62)$ & \\
\hline
\end{tabular}

Means followed by the same lowercase letter in the column and the same uppercase letter in the row, do not differ by Tukey's test. *Significant at the $5 \%$ probability level $(0.01=<\mathrm{p}<0.05)$. Values in parentheses are the standard deviation.

Where: T - Treatment; NT - Wood in natura; T - Thermally modified wood; JH - Janka Hardness; SID - Steel ball impact depressions. 


\section{Indentation index}

In Table 4, the indentation indexes obtained in natura and thermally modified wood of each clone, it can be seen that $E$. urophylla had the lowest indexes, while the highest indexes were observed in the thermally modified wood of E. grandis x E. urophylla of masal selection and in the natural wood of E. grandis x E. urophylla of controlled pollination; which assumes that $E$. urophylla has greater resistance to the impact of falling objects at $1.80 \mathrm{~m}$ from height, in relation to the other clones.

Table 4. Indentation index for natural and thermally modified woods of the four Eucalyptus clones.

Tabela 4. Índice de endentação para as madeiras in natura e modificada termicamente dos quatro clones de eucalipto.

\begin{tabular}{|c|c|c|c|c|c|c|c|}
\hline \multirow[t]{2}{*}{ Clones } & \multirow[t]{2}{*}{$\mathrm{T}$. } & \multicolumn{5}{|c|}{ Adjusted equation } & \multirow{2}{*}{$\begin{array}{l}\text { Indentation } \\
\text { index }\end{array}$} \\
\hline & & $\mathrm{B}_{0}$ & $\mathrm{~B}_{1}$ & $R_{a j}^{2}$ & $S_{y x}(\%)$ & $F$ & \\
\hline E.grandis $\mathrm{x}$ E.urophylla & NT & 0.06 & 0.004 & 0.75 & 12.08 & $76.07 *$ & 0.694 \\
\hline Masal selection & $\mathrm{T}$ & 0.07 & 0.006 & 0.67 & 25.12 & $61.33^{*}$ & 1.202 \\
\hline E.grandis & NT & -0.01 & 0.004 & 0.87 & 8.51 & $187.44 *$ & 0.695 \\
\hline Masal selection & $\mathrm{T}$ & -0.05 & 0.005 & 0.77 & 17.02 & $88.31 *$ & 1.014 \\
\hline E.grandis $\mathrm{x}$ E.urophylla & NT & -0.01 & 0.004 & 0.73 & 14.55 & $84.52 *$ & 0.751 \\
\hline Controlled pollination & $\mathrm{T}$ & -0.02 & 0.007 & 0.81 & 18.36 & $119.7 *$ & 1.192 \\
\hline E.urophylla & NT & -0.02 & 0.004 & 0.90 & 6.84 & $287.61 *$ & 0.633 \\
\hline Masal selection & $\mathrm{T}$ & 0.098 & 0.004 & 0.48 & 23.65 & $20.13^{\mathrm{ns}}$ & 0.835 \\
\hline
\end{tabular}

Where: $\mathrm{B}_{0}$ : Estimated model coefficient; $\mathrm{B}_{1}$ : Steel ball drop height coefficient $*$ Significant at the $5 \%$ probability level; $\mathrm{R}^{2}{ }_{\mathrm{aj}}=\mathrm{Adjusted}$ coefficient of determination; $\mathrm{S}_{\mathrm{yx}} \%=$ Standard error of the estimate; $\mathrm{F}=$ calculated significance factor. $\mathrm{T}$ - Treatment; NT - Wood in natura; $\mathrm{T}$ - Thermally modified wood

\section{Depressions by concentrated and distributed load}

The tests of continuous application of concentrated load and distributed load, presented in table 5 demonstrate that the depressions caused showed significant differences in the surfaces of in natura and thermally modified wood of the four clones; and the smallest depressions were observed in the masal selection E. urophylla, whereas the E. grandis x E. urophylla of masal selection had the highest depressions.

Table 5. Concentrated and distributed load depressions in natural and thermally modified woods of four eucalyptus clones.

Tabela 5. Depressões por cargas concentrada e distribuída nas madeiras in natura e modificada termicamente de quatro clones de eucalipto.

\begin{tabular}{|c|c|c|c|c|c|c|}
\hline \multirow[t]{2}{*}{ Depressions } & \multirow[t]{2}{*}{$\mathrm{T}$} & \multicolumn{2}{|c|}{ Clones } & & & \multirow[t]{2}{*}{$\mathrm{F}$} \\
\hline & & $\begin{array}{l}\text { E.grandis } \\
\text { xE.urophylla } \\
\text { Massal } \\
\text { selection }\end{array}$ & $\begin{array}{l}\text { E.grandis } \\
\text { Massal } \\
\text { selection }\end{array}$ & $\begin{array}{l}\text { E.grandis } \\
\mathrm{x} \text { E.urophylla } \\
\text { Controlled } \\
\text { pollination }\end{array}$ & $\begin{array}{l}\text { E.urophylla } \\
\text { Massal } \\
\text { selection }\end{array}$ & \\
\hline \multirow{4}{*}{$\begin{array}{l}\text { D.C.L. } \\
\text { Passes } \\
(\mathrm{mm})\end{array}$} & NT & $1.05 \mathrm{Aa}$ & $0.61 \mathrm{Ca}$ & $0.84 \mathrm{Ba}$ & $0.43 \mathrm{Da}$ & \multirow[t]{4}{*}{$5.60 *$} \\
\hline & & $*(23.50)$ & $*(28.52)$ & $*(19.54)$ & $*(25.84)$ & \\
\hline & $\mathrm{T}$ & $2.22 \mathrm{Ab}$ & $0.91 \mathrm{Cb}$ & $1.81 \mathrm{Bb}$ & $0.85 \mathrm{Db}$ & \\
\hline & & $*(29.09)$ & $*(23.12)$ & $*(26.37)$ & $*(23.16)$ & \\
\hline \multirow{4}{*}{$\begin{array}{l}\text { D.D.L. } \\
\text { passes } \\
(\mathrm{mm})\end{array}$} & NT & $0.11 \mathrm{Ab}$ & $0.08 \mathrm{Bb}$ & $0.08 \mathrm{Bb}$ & $0.03 \mathrm{Cb}$ & \multirow[t]{4}{*}{$1.63 *$} \\
\hline & & $*(27.29)$ & $*(24.27)$ & $*(30.18)$ & $*(28.37)$ & \\
\hline & $\mathrm{T}$ & $0.22 \mathrm{Aa}$ & $0.10 \mathrm{Ba}$ & $0.12 \mathrm{Ba}$ & $0.11 \mathrm{Ba}$ & \\
\hline & & $*(30.69)$ & $*(29.62)$ & $*(26.24)$ & $*(27.87)$ & \\
\hline
\end{tabular}

Averages followed by the same lowercase letter in the column and the same uppercase letter in the row, do not differ by the Tukey test * Significant at the level of $5 \%$ probability $(0.01=<p<0.05)$. Values in parentheses are the standard deviation.

Where: D.C.L. - Depressions by concentrated load; D.D.L. - Depressions by distributed load; T T - Treatment; NT - Wood in natura; T Thermally modified wood

\section{DISCUSSION}

\section{Physical properties}

It can be observed that for these properties, in E. grandis x E. urophylla of massal selection E. grandis, the temperature caused greater loss of particles and woody material per unit volume; while in E. grandis $\mathrm{x} E$. urophylla of controlled pollination and E. urophylla, the temperature used in the process resulted in the removal of water, without intense degradation of the particles of the molecular chemical components. 
This observation was also reported by Brito et al. (2008), in the thermal modification of $E$. grandis wood in an electric oven, attributing the inefficiency of the pyrolysis phases, to cause loss of mass in some species during the process. In another study, Santos et al. (2014), when evaluating the thermal modification of wood of Cedrelinga catenaeformis and Guarea trichilioides in an electric oven, found an increase in the apparent specific mass.

The average values of the apparent specific mass obtained after the thermal modification of E. grandis $\mathrm{x}$ E. urophylla of controlled pollination and E. grandis, were relatively low in relation to the values obtained by Calonego et al. (2014) in E. grandis wood. The results observed in this study for this property in E. grandis x E. urophylla of controlled pollination and E. urophylla were relatively greater in relation to the observations of the same authors.

Still in Table 2, the mass loss was statistically equal between E. grandis x E. urophylla of massal selection, E. grandis and E. urophylla; which showed relatively less thermal degradation in relation to E. grandis $\mathrm{x} E$. urophylla of controlled pollination, which had the greatest degradation.

It is a fact that cellulose and hemicellulose molecules are the main chemical components of hardwoods. In this context, it can be seen that E. grandis x E. urophylla of controlled pollination, which had a higher proportion of holocelluloses, showed greater degradation because these are the ones that most degrade during the process of thermal modification, resulting in greater weight loss.

In this context, research conducted by Santos et al. (2014) on Cedrelinga Catenaeformis and Guarea trichilioides wood, found relatively low weight loss percentages. Similar to the results presented in Table 2 , Carrasco et al. (2016) using eucalyptus wood, also obtained relatively high percentages of mass loss.

\section{Chemical properties}

The levels of lignin, showed significant increases after the thermal modification, promoted by the resistance in its decomposition, and respective association between these molecules, with the new substances that are formed in the degradation of celluloses and hemicelluloses during the different phases of thermal modification. This situation was reported by Yildiz et al. (2013) according to which temperatures from $200^{\circ} \mathrm{C}$ begin to crystallize from this molecule that does not degrade during the process of thermal modification.

Despite the increase, the levels of lignin observed can be considered relatively low, probably because they are wood from plantations intended for the production of cellulose and paper, a sector that prioritizes greater cellulose pulp yield.

For this component, the results obtained were similar to the observations of Zanuncio et al. (2014) using 200 degrees for 3 hours and 5 hours of exposure of Eucalyptus grandis wood. Brito et al. (2008), on the other hand, using lower temperatures observed an increase in lignin levels in Eucalyptus saligna wood, evidencing the influence of temperature for the availability of this chemical component.

The content of holocelluloses showed a significant decrease after the thermal modification of the four clones, due to the high temperatures used in the process, which resulted in the breaking of bonds between the hydroxyl groups, promoted by the degradation of the hemicellulose and cellulose molecules, which are less stable in relation to the lignin molecules.

Similar results were observed by Yildiz et al. (2013), according to which, the breakdown of chemical bonds in hemicellulose and cellulose molecules intensifies from $100^{\circ} \mathrm{C}$, generating new products and volatile and flammable compounds respectively, depending on the atmoball in which the process is carried out.

Zanuncio et al. (2014) obtained similar results when using $200^{\circ} \mathrm{C}$ in 3,5 and 7 hours of exposure of Eucalyptus grandis wood. However, Silva et al. (2015) when using the same temperatures found a greater reduction in the content of holocelluloses in Corymbia citriodora wood submitted to thermal modification in the presence of nitrogen, which, as a gas, provides greater intensity of thermal degradation of the wood.

\section{Hardness and impact}

In Table 3, it can be seen that the thermal modification resulted in improvements in the surface hardness of E. urophylla, in which there was an increase in the resistance to the penetration of the ball in the wood surface after submission to high temperatures used in the process, a situation that was not observed in the other tested clones.

For Percin et al. (2016) the increase in surface hardness can occur at the beginning of thermal modification, as a result of the condensation processes of lignin and cellulose, forming new chemical bonds. For this property, the most common is that observed in E. grandis x E. urophylla of massal selection, E. grandis and E. urophylla, which presented less intense degradations in relation to $E$. grandis, in which there was a reduction in surface hardness, motivated by the degradation of the molecular components during the temperature rise.

Table 3 shows a direct relationship between the surface hardness and specific mass of the wood, due to the proportional degradation of the woody material with the volatilization of the substances obtained in the degradation of holocelluloses, causing a reduction in Janka hardness, similar to the results obtained by Korkut $e t$ al. (2008) in Corylus coluna wood. 
For the depressions caused by impact on the ball fall at 1.80 meters from height, also shown in Table 3, significant differences were observed between the in natura wood and thermally modified of the four clones, being that separately the in natura woods of E. grandis x E. urophylla of controlled pollination showed a higher absolute value of depression without statistical difference with the other clones.

In the case of thermally modified wood, E. urophylla, presented lower average depression, caused by the fall of the steel ball, with significant differences in relation to the other clones that had greater depressions.

By the values of depressions presented in the two wood conditions of the four clones, it is observed that the energy absorption generated by the ball at the moment of the fall was greater in the thermally modified wood, except for the clone E. urophylla, in which the difference in depression before and after the thermal modification was practically null.

The fact that the analyzes were carried out at 1.80 meters in height because it is considered critical may have contributed to the generation of greater impact, due to the greater distance covered by the ball, a situation that resulted in the greater energy accumulating and discharged on the specimens of these clones, agreeing with Blanco-Florez et al. (2015), which state that when the steel ball is released from inertia on the surface of the wood, it absorbs the impact energy and causes deformation, which is increased with increasing fall distance.

In comparison with these results, Padilha et al. (2006) in eucalyptus wood, obtained lower depression values, ranging from $0.47 \mathrm{~mm}$ to $0.53 \mathrm{~mm}$. These results imply care for the use of young eucalyptus woods. And in the case of E. urophylla floors that presented the best response, there is still a need to avoid falling objects on them above heights of one meter, due to the susceptibility of irreversible deformations that compromise the visual and aesthetic aspect.

\section{Indentation index}

In Table 4, the maximum depth limits of the depressions that E. grandis x E. urophylla of controlled pollination can reach are $0.63 \mathrm{~mm}$ and $0.83 \mathrm{~mm}$ in natura and thermally modified wood respectively; compared to the other clones that can withstand greater depths in the fall of the ball, reaching a little more than $1 \mathrm{~cm}$ in thermally modified wood.

Also in Table 4, the models developed to estimate the maximum depth of depression of the four clones were satisfactory and significant, with the exception of the thermally modified wood of E. urophylla, in which the height of fall is not the only factor that interfered in the limit of resistance to the impact of the floors.

This situation implies considering other variables, which possibly affect the resistance limit of the modified wood of this clone, among them the density of the wood, the difference in the degradation of the holocelluloses after the thermal modification and the tested faces, because it was possible to observe some differences in depth caused by the impact, in the parts with tangential face in relation to the parts with radial face.

For this index, Martins et al. (2013) obtained $0.2 \mathrm{~mm} ; 0.24 \mathrm{~mm}$ and $0.28 \mathrm{~mm}$, respectively, in Corymbia maculata and E. microcorys wood with 32 years old and E. cloeziana wood with 22 years old; situations that show the influence of wood quality as a factor to obtain lower rates and with better performance in the simulation of falling objects.

\section{Depressions by concentrated and distributed load}

For this test, it can be seen in table 5, that in natura wood, in addition to the effect of the applied load, the depressions caused are the result of the low specific mass of the wood, mainly in E. grandis x E. urophylla of massal selection and E. grandis $\mathrm{x}$ E. urophylla of controlled pollination.

After the thermal modification of the wood, this trend was altered, since there was variation in the specific masses, having increased in E. grandis x E. urophylla of controlled pollination and E. urophylla, but with respective decreases in the measured depressions.

The behavioral difference may also be associated with differences in the degradation of chemical components between the four clones. As was observed in the chemical analyzes in which E. urophylla presented a greater availability of lignin, a molecule that is associated with greater resistance of wood, influencing the better behavior of the respective clone in the concentrated load test.

Considering that the tests were performed only with 25 passes, it can be said that the values of depressions obtained for the tested clones were high, similar to what was observed by Padilha et al. (2006) in E. urophylla, which found residual and instantaneous depressions ranging from $1.6 \mathrm{~mm}$ to $5.4 \mathrm{~mm}$. On the other hand, Santos et al. (2010) in E. urophylla wood erected relatively low depressions for wood qualification by applying rolling load.

Still in table 5, it is observed that the depressions in the wood, caused by the load distributed in the pointed teeth contained in the cylindrical roller; also showed significant differences between the clones both for in natura wood and for thermally modified wood, after 50 passes.

However, contrary to the application of rolling load, the indentation test for distributed load caused relatively lower depressions in the 50 passes made. From the analyzes made on the four eucalyptus clones, some 
similarities can be observed in the behavior of the depressions, in which E. grandis and E. urophylla had lower depressions, both in natura wood and in thermally modified wood.

E. grandis $\mathrm{x}$ E. urophylla of massal selection and E. grandis $\mathrm{x}$ E. urophylla of controlled pollination showed greater depressions in fresh and thermally modified wood, showing themselves as the worst for use as floors. It is worth mentioning that the natural selection of E. grandis x E. urophylla of massal selection did not present any change in the depressions in 50 passes of the indented roller, most likely due to the low density of the respective clone in relation to the others; being easily caused by the excessive compaction of the roller, reaching its maximum limit in the first 50 passes.

For thermally modified wood of E. grandis x E. urophylla of massal selection, a relatively different situation was observed, promoted by the reduction of specific mass. These observations were reported by Martins et al. (2013), according to which, the compaction suffered by the wood after continuous passes ends up causing greater mechanical resistance and, consequently, reduction of the depressions in the wood.

In this assay, the depressions obtained in 50 roll passes in the in natura wood of E. grandis, E. grandis $\mathrm{x}$ E. urophylla of controlled pollination were similar to the observations from Santos et al. (2010) in clone MN 89, in woods obtained in the internal, intermediate and external regions of the trunk, and after the thermal modification there was an increase in these properties.

Still for in natura wood, the values observed in E. grandis, E. grandis x E. urophylla of controlled pollination and E. urophylla were similar to the results of Padilha et al. (2006) when evaluating eucalyptus clones; as well as the observations by Martins et al. (2013) who determined $0.04 \mathrm{mms}$ in C. maculata and $0.05 \mathrm{~mm}$ in $E$. microcorys.

After thermal modification, with the exception of E. grandis x E. urophylla of massal selection, the average values of indentations caused by 50 passes in the other clones were similar to the values obtained by Blanco-Florez et al. (2015) with Tectona grandis wood.

For the qualification of the floors, there was a relatively different behavior in the resistance limits for each test, and with the exception of E. urophylla, which was obtained from matrices with good resistance characteristics, the thermal modification of the remaining clones reduced the performance of the floors, as they showed weaknesses and a tendency to break after intense use simulation.

\section{CONCLUSIONS}

- The thermal modification did not cause significant changes in the apparent density.

- There was an increase in lignin and depressions in loading efforts with a decrease in holocelluloses contents after the thermal modification of the wood.

- In Janka hardness tests, the in natura and thermally modified woods of E. grandis and E. urophylla showed the best results.

- The thermal modification favored the wood of the E. urophylla clone in the rolling load, indentation and impact tests in steel ball, which was the best among the tested clones.

- The thermal modifications in the E. urophylla woods allowed to obtain floors with characteristics to be used in playgrounds, garden decks, swimming pools, saunas and offices.

\section{REFERENCES}

AMERICAN SOCIETY FOR TESTING AND MATERIALS. ASTM D143-14, Standard Test Methods for Small Clear Specimens of Timber.West conshohocken, 2014.

AMERICAN SOCIETY FOR TESTING AND MATERIALS. ASTM - D 2394-83. Simulated service testing of Wood and Wood-base finish flooring, Annual book of ASTM Standards, 2011.

BLANCO-FLÓREZ, J.; SILVA, J.R.M.; BRAGA, P.P.C.; LIMA, J.T.; TRUGILHO, P.F. Simulação em serviço de pisos de madeira jovem de Tectona grandis. Revista Matéria, v.20, n.4, p.1048-1060, 2015.

BRITO, J.O.; SILVA, F.G.; LEÃO, M.M.; ALMEIDA, G. Chemical composition changes in Eucalyptus and Pinus woods submitted to heat treatment. Bioresource Technology, v.99, n.18, p.8545-8548, 2008.

CADEMARTORI, P.H.G.; MISSIO, A. L.; MATTOS, B.D.; GATTO, D.A. Effect of thermal treatments on technological properties of wood from two Eucalyptus species. Anais da Academia Brasileira de Ciências, v.87, n.1, p.471-481, 2015.

CALONEGO, F.W.; SEVERO, E.T.D.; LATORRACA, J.V. Effect of Thermal Modification on the Physical Properties of Juvenile and Mature Woods of Eucalyptus grandis. Floresta e Ambiente, v.21, n.1, p.108-113, 2014. 
CARRASCO, E.V.M.; OLIVEIRA, A.L.C.; MANTILLA, J.N.R. Influência da temperatura na resistência e no módulo de elasticidade em madeira de híbridos de Eucaliptos. Ciência Florestal, v.26, n.2, p.389-400, 2016.

HARDWOOD REVIEW, Market Opportunity: Heat-treated Hardwoods, European Technology has Chance to Grow. Review Express, v. 8, n.15, 2009.

INDÚSTRIA BRASILEIRA DE ÁRVORES - Ibá. Relatório 2017Ibá, Available in: < https://iba.org/images/shared/Biblioteca/IBA_RelatorioAnual2017.pdf> Accessed on: 02/18/2020.

KORKUT, D.S.; KORKUT, S.; BEKAR, I.; BUDAKÇI, M.; DILIK, T.; ÇAKICIER, N. The effects of heat treatment on the physical properties and surface roughness of Turkish Hazel (Corylus colurna L.). Wood. Int J Mol Sci, v.9, n.9, p.1772-1783. 2008.

MARTINS, M.; SILVA, J.R.M.; LIMA, J.T.; GONÇALVES, M.T.T.; FILIPE, A.P. Simulação em uso dos pisos de madeira de Eucalyptus sp e Corymbia maculata. Revista Cerne, Lavras, v.19, n.1, p.151-156, 2013.

MODES, K.S.; SANTINI, E.J.; VIVIAN, M.A.; HASELEIN, C.R. efeito da termorretificação nas propriedades mecânicas das madeiras de Pinus taeda e Eucalyptus grandis. Ciência Florestal, Santa Maria, v. 27, n. 1, p. 291$302,2017$.

PADILHA, C.; LIMA, J.T.; SILVA, J.R.M.; TRUGILHO, P.F.; ANDRADE, H.B. Avaliação da qualidade da madeira de Eucalyptus urophylla para utilização em pisos. Scientia Forestalis, n. 71, p.141-147, Agosto 2006.

PERCIN, O.; PEKER, H.; ATILGAN, A. The effect of heat treatment on the some physical and mechanical properties of beech (Fagus orientalis lipsky) wood. Wood research, v.61, n.3, p.443-456, 2016.

SANTOS, D.V.B.; DE MOURA, L.F.; BRITO, J.O. Effect of heat treatment on color, weight loss, specific gravity and equilibrium moisture content of two low market valued tropical Woods. Wood research, v.59 n.2, p.253-264, 2014.

SANTOS, I.S.; LIMA, J,T.; SILVA, J.R.M. Avaliação dos pisos produzidos a partir de toras de clones de Eucalyptus sp. com pequenos diâmetros. Cerne, v.16, n.4, p.473-478. 2010.

SILVA, M.R.; BRITO, J.O.; GOVONE, J.S.; MACHADO, G.O.; JUNIOR, C.C.; CHRISTOFORO, A.L.; LAHR, F.A.R. Chemical and mechanical properties changes in Corymbia citriodora wood submitted to heat treatment. International Journal of Materials Engineering, v.5, n.4, p.98-104. 2015.

TAPPI. Solvent extractives of wood and pulp - TAPPI T $204 \mathrm{~cm}-97$. In: (Ed.). Technical Association of the Pulp and Paper Industry Atlanta, USA, 1997.

TAPPI. Acid-insoluble lignina in wood and pulp - TAPPI 222 om-98. In: (Ed.). Technical Association of the Pulp and Paper Industry. Test Methods 2000-2001. Atlanta, USA, 1998.

YILDIZ, S.; TOMAK, E.D.; YILDIZ, C.; USTAOMER, D. Effect of artificial weathering on the properties of heat treated Wood. Polymer Degradation and Stability, n.98, v.8, p.1419-1427, 2013.

ZANUNCIO, A.J.V.; NOBRE, J.R.C.; MOTTA, J.P.; TRUGILHO, P.F.; Química e colorimetria da madeira de Eucalyptus grandis W. Mill ex Maiden termorretificada. Árvore, v.38, n.4, p.765-770, 2014. 